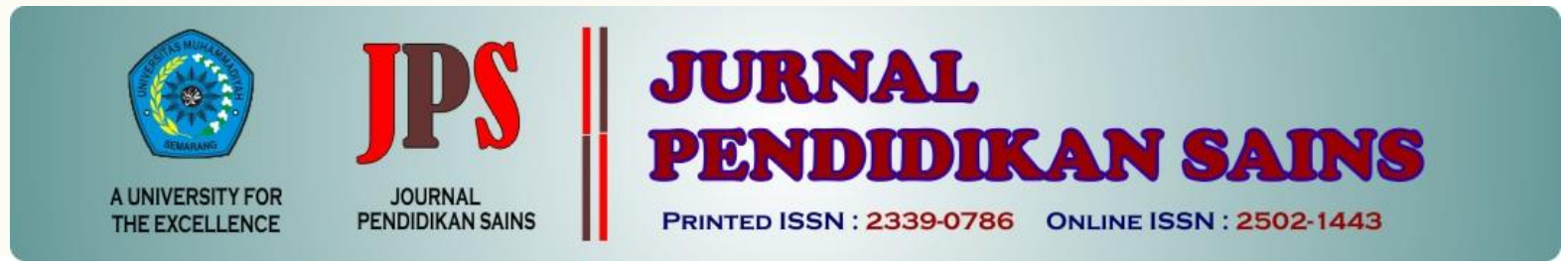

http://jurnal.unimus.ac.id/index.php/JPKIMIA

\title{
PERANGKAT PEMBELAJARAN BIOLOGI BERBASIS PROBLEM BASED LEARNING YANG BERORIENTASI KEMAMPUAN METAKOGNITIF
}

\author{
Oleh: \\ Andi Asyhari \\ Institut Agama Islam Negeri Kudus
}

\begin{tabular}{ll}
\hline \multicolumn{2}{l}{ Article history } \\
\hline Submission & $: 2020-01-13$ \\
Revised & $: 2020-09-07$ \\
Accepted & $: 2020-09-23$
\end{tabular}

Keyword:

learning device, metacognition, problem based learning

\begin{abstract}
Problem-based learning (PBL) in biology has been considered as one of the innovative contextual teaching designs, since students learn biology from problems (cases) of real life and it potentially encourage students' metacognition. This research was aimed at developing biology teaching devices, grounded in problem-based learning approaches and metacognition habits, and identifying their effect on students' learning achievement and metacognition. The large field testing was implemented on 33 students, using pre-experimental design group single pre-test - post test design. Experimental data was analysed quantitatively. The findings showed that (1) there was a significant effect of the use of the innovative lesson devices on student learning achievement and metacognition which is measured using questionnaire metacognitive (MAI). Metacognition scores were more likely to be improved, before and after treatment (0.36 middle). High metecognition scores were on planning aspects ( 0.42 middle) and the lowest score of metecognition was on executing aspects (0,29); (2) learning achievement was also improved, before and after treatment. $\mathrm{N}$-gain score was 0.52 (middle). The total contribution of the lesson design on learning achievement and metacognition was classfied 'highly effective'.
\end{abstract}

\section{Pendahuluan}

Perangkat pembelajaran berkaitan dengan kualitas pembelajaran, Apa yang dikerjakan siswa dipengaruhi oleh desain perangkat pembelajaran yang diciptakan oleh guru. Perangkat pembelajaran merupakan desain pembelajaran yang dikembangkan untuk mencapai tujuan pembelajaran. Perangkat pembelajaran didalamnya tercermin tujuan pembelajaran, materi, dan cara guru menilai siswa dalam mencapai tujuan. Materi yang menarik dan dikemas dalam desain pembelajaran memberi kesan tersendiri bagi siswa. Salah satu topik yang menarik dalam pembelajaran biologi adalah sistem imun yang didalamnya mempelajari kasuskasus kelainan imunitas di dalam tubuh. Penyakit adalah fenomena anomali tubuh yang pemahamannya menuntut pemikiran tingkat tinggi dan berpikir metakognitif siswa. Guru IPA secara kreatif dan inovatif dapat mengembangkan perangkat pembelajaran berbasis kasus anomali tubuh untuk membiasakan berpikir metakognitif.

\footnotetext{
*Corresponding Author:

Nama : Andi Asyhari

Lembaga : Institut Agama Islam Negeri Kudus

Email : andykalem2014@gmail.com
} 
Problem-based-Learning (PBL) merupakan salah satu pendekatan merupakan pendekatan pembelajaran innovatif, yang menggunakan masalah (kasus) sebagai pondasi kegiatan siswa serta mendorong menjadi pembelajar mandiri. (Akcay, 2009). PBL dirancang untuk meningkatkan kemampuan berpikir tingkat tinggi siswa, khususnya kemampuan metakognitif (Dyahwati et al., 2013, Lubana et al., 2013). PBL dapat digunakan untuk membantu melatih kemampuan metakognitif siswa yang mengarah pada pemecahan masalah, khususnya kemampuan metakognitif dalam hal selfmonitoring dan planning (Biryukov, 2004).

Metakognitif merupakan pengetahuan yang berasal dari proses kognitif beserta hasil-hasilnya. Livingston (2002) mengibaratkan antara pengetahuan dan pengalaman metakognitif layaknya teori dan praktik. Menurut Suherman et al., (2001) metakognitif merupakan suatu kata yang berkaitan dengan apa yang diketahui tentang dirinya sebagai individu yang belajar dan bagaimana dia mengontrol serta menyesuaikan perilakunya. Seseorang perlu menyadari kekurangan dan kelebihan yang dimilikinya. Metakognitif adalah suatu bentuk kemampuan untuk melihat pada diri sendiri sehingga apa yang dilakukan dapat terkontrol secara optimal. Kemampuan seperti ini memungkinkan seseorang memiliki kemampuan tinggi dalam memecahkan masalah. (Downing, 2008). Toit, S. D \& Gary, K (2008) menyatakan bahwa metakognisi setidaknya harus mencakup aspek-aspek pengetahuan tentang pengetahuan seseorang, pemantauan secara sadar, mengatur pengetahuan seseorang, kondisi kognitif dan afektif. Metakognitif dapat dipandang sebagai bagian model monitoring yang menunjukkan hubungan dinamis antara empat komponen yaitu metacognitive knowledge, metakognitif experience, goals (or taks), dan actions. Metakognitif memiliki peran penting dalam pembelajaran khsusnya berpengaruh terhadap prestasi belajar siswa. Siswa yang memiliki kesadaran metakognisi lebih tinggi akan memiliki kemampuan lebih baik dalam perencaan, pengelolaan informasi, pemantauan, pelaksanaan dan evaluasi, dibanding siswa yang memiliki kemampuan metakognisi rendah (Penggayuh, V. 2017)

Berdasarkan uraian tersebut maka penelitian ini bertujuan untuk mengembangkan perangkat pembelajaran berbasis PBL dan melihat pengaruh perangkat pembelajaran berbasis PBL terhadap hasil belajar dan kemampuan metakognitif siswa serta

\section{Metode Penelitian}

Penelitian dilakukan dengan pendekatan Research and Development dalam empat tahapan utama yaitu: 1) studi pendahuluan, 2) pengembangan produk, 3) uji coba produk, 4) revisi Sugiyono (2010). Pada tahap awal dilakukan studi pendahuluan untuk melakukan analisis kebutuhan dengan melakukan analisis kurikulum, kemampuan akademik, dan perangkat pembelajaran. Pada tahap ujicoba skala kecil dilakukan pada siswa kelas XII MIA 2 untuk melihat tingkat keterbacaan perangkat yang dikembangkan. Ujicoba skala luas dilakuakan pada siswa kelas XI MIA 2. Desain penelitian pada tahap ujicoba skala luas adalah pra experimental design. Populasi yang digunakan adalah siswa kelas XI MIA I sebanyak 33 siswa. Desain penelitian yang digunakan adalah pre experimental design dengan menggunaka metode "One-Group Pre-test-Post-test Design". Hasil penelitian berupa peningkatan kemampuan metakognitif dan hasil belajar yang diukur menggunakan instrumen lembar angket metakognitif MAI (Metcognitioan awearnes inventory) dan jurnal reflektif pembelajaran. Hasil belajar diukur dengan soal pre-test dan post-test. Analisis data menggunakan uji N-Gain untuk melihat peningkatan kemampuan metakognitf dan hasil belajar.

\section{Hasil Penelitian dan Pembahasan}

Penyajian hasil penelitian ini untuk memberikan gambaran perolehan data secara umum di lapangan. Data hasil penelitian yang disajikan meliputi hasil pengembangan Perangkat Pembeljaran berbasis PBL pada materi system imun dan hasil analisis pengaruh penggunaan perangkat pembelajaran berbasisi PBL terhadap hasil belajar kemampuan metakognitif siswa

\section{Karakteristik Perangkat Yang Telah Dikembangkan}

Hasil pengembangan perangkat yang dilakukan pada tahap pengembangan baik RPP, bahan ajar, LKS dan evaluasi memiliki karakteristik perangkat pembelajaran yang disajikan pada Tabel 1.

Tabel 1. Gambaran Karakteristik perangkat pembelajaran yang Telah dikembangkan

\begin{tabular}{lll}
\hline Perangkat & Komponen & \multicolumn{1}{c}{ Keterangan } \\
\hline Silabus & Indikator & $\begin{array}{l}\text { Indikator mengandung } \\
\text { komponen metakognitif } \\
\text { (perencanaan, monitoring, } \\
\end{array}$ \\
& & pelaksanaan, dan evaluasi)
\end{tabular}




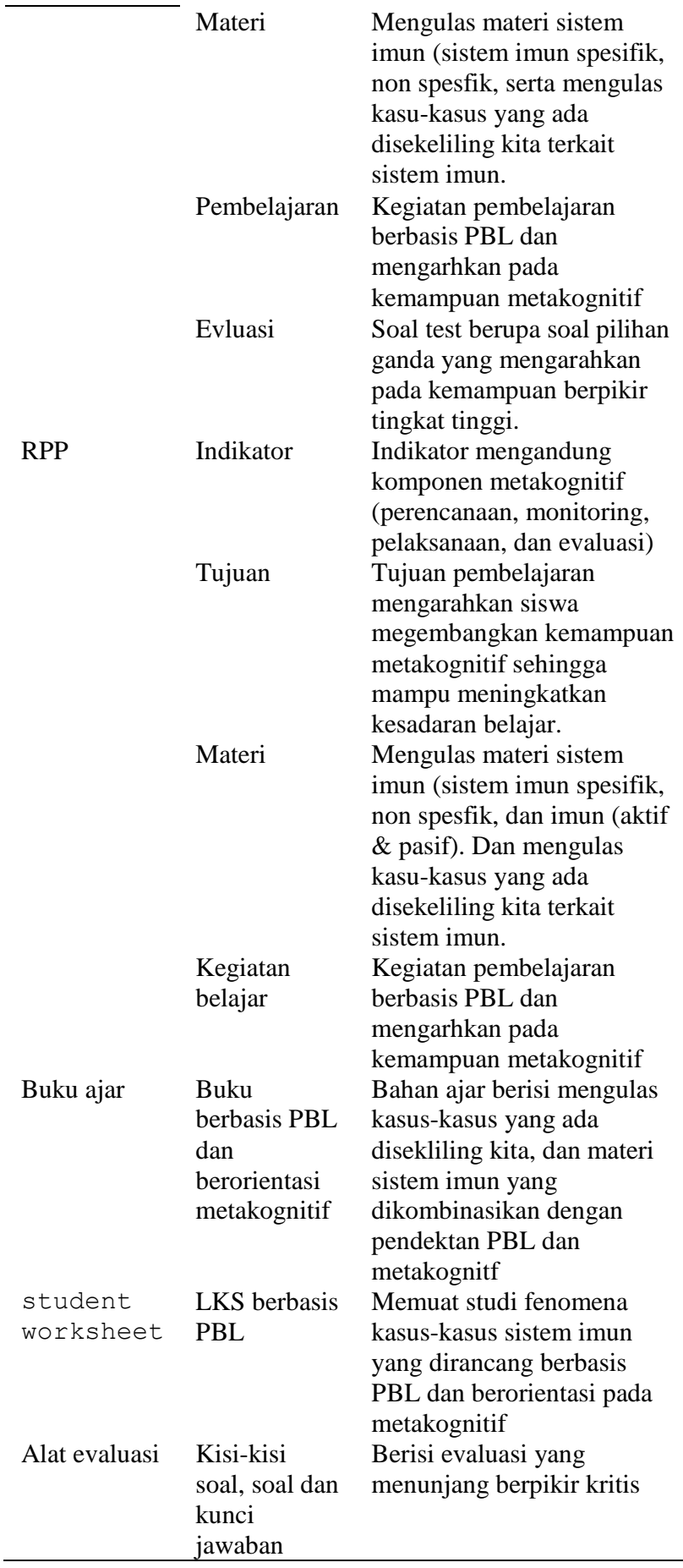

Perangkat pembelajaran yang telah dikembangkan berbasis PBL dan berorientasi pada kemampuan metakognitif. RPP dikembangkan berbasis PBL dan berorientasi pada metakognitif dikarenakan lebih memudahkan siswa untuk belajar menjadi pembelajar mandiri, hal tersebut didasari hasil penelitian Wulandari et al., (2011) menyatakan PBL merupakan cara konstruktif dalam pembelajaran dengan menggunakan permasalahan sebagai stimulus yang berfokus kepada aktivitas pelajar. PBL bukan untuk membantu guru memberikan banyak informasi kepada siswa tetapi PBL dirancang untuk membantu siswa mengembangkan cara berpikir, penyelesaian masalah, belajar menjadi orang dewasa, dan menjadi pembelajar mandiri (Sugiman, 2007).

Bahan ajar yang dikembangkan berbasis PBL dan berorientasi pada metakognitif, yang memuat berupa cuplikan sebuah kasus atau isu-isu sosial yang ada di sekitar guna menunjang kemudahan dalam mempelajari konsep sistem imun. Penggunaan isu-isu sosial dalam pengembangan bahan ajar ini didasari hasil penelitian dari Barab et al., (2010) menyatakan bahwa penggunaan socio scientific isu dapat memancing ketrampilan penyelidikan atau investigasi.

LKS disajikan berbasis PBL dan pembalejaran yang dihubungakan dengan konsep yang dibahas untuk menstimulus kemampuan metakognitif siswa dan hasil belajar siswa. kondisi tersebut sesuai dengan hasil penelitian Downing (2010) menyatakan bahwa pembelajaran berbasis masalah secara teori dan idealnya dapat digunakan untuk meningkatkan lebih cepat keterampilan metakognitif. Siswa yang memiliki kemampuan metakognitif secara otomatis akan memiliki motivasi yang tinggi dalam belajar. Oleh karena siswa yang memiliki motivasi yang tinggi akan berpengaruh terhadap prestasi belajar siswa.

\section{Hasil Belajar}

Analisis data peningkatan hasil belajar materi sistem imun dihitung dengan menggunakan nilai $N$-Gain. Hasil analisis $N$-Gain kelas XI MIA 1 menghasilkan rata-rata tingkat pencapaian sebesar 0,52 dan masuk pada kategori sedang. Hasil uji $\mathrm{N}$-gain menunjukkan 3 siswa masuk dalam kategori tinggi dari 33 siswa, selebihnya 24 siswa masuk dalam kategori sedang, dan 9 siswa masuk dalam kategori rendah. Nilai hasil $\mathrm{N}$-gain disajikan pada Tabel 2

Tabel 2. Hasil nilai pre-test dan post-test dan $N$-gain

\begin{tabular}{lccccc}
\multicolumn{5}{c}{ dan $N$-gain } \\
$\begin{array}{l}\text { Kelompok } \\
\text { Siswa }\end{array}$ & $\begin{array}{c}\text { N } \\
\text { jumlah }\end{array}$ & $\begin{array}{c}\text { Rata- } \\
\text { rata } \\
\text { Pre- } \\
\text { test }\end{array}$ & $\begin{array}{c}\text { Rata- } \\
\text { rata } \\
\text { Post- } \\
\text { test }\end{array}$ & $\begin{array}{c}\text { Nain } \\
\text { gain }\end{array}$ & Keterangan \\
\hline Tinggi & 10 & 57.60 & 82.00 & 0.57 & Sedang \\
Sedang & 17 & 56.25 & 77.63 & 0.49 & Sedang \\
Rendah & 6 & 49.33 & 73.67 & 0.47 & Sedang \\
Keseluruhan & 33 & 55,64 & 78,61 & 0.52 & Sedang \\
\hline
\end{tabular}

Hasil nilai pre-test dan post-test menunjukkan bahwa rata-rata siswa mengalami peningkatan hasil nilai pre-test dan post-test pada kategori sedang untuk tiap kelompok siswa, baik dari kelompok rendah sampai kelompok tinggi. Hasil rata-rata pre-test dan post-test mengalami 
peningkatan dari kelompok siswa berkemampuan rendah sampai kelompok siswa berkemampuan tinggi.

Rata-rata hasil nilai pre-test dan post-tes yang di uji $N$-gain, siswa yang sudah dikategorikan mengalami peningkatan kategori sedang. Kondisi tersebut dikarenakan proses pembelajaran berbasis PBL yang berorientasi pada kemampuan metakognitif mampu meningkatkan pemahaman dan kesadara belajar siswa, sehingga terjadi peningkatan hasil belajar siswa. Dapat disimpulkan bahwa penerapan perangkat pembelajaran berbasis PBL dan berorientasi pada kemampuan metakognitif dapat dikatakan efektif dalam meningkatkan hasil belajar siswa. Sesuai hasil penelitian Wulandari et al., (2011) mendapati bahwa PBL berpengaruh secara signifikan terhadap hasil belajar yang diperoleh siswa.

Hasil ketiga kelompok siswa baik kelompok siswa tinggi, sedang, dan rendah menunjukkan kecenderungan peningkatan hasil nilai pre-test dan post-test. Kelompok siswa mendapatkan ratarata peningkatan pada kategori sedang, peningkatan hasil nilai pre-test dan post-test tertinggi terjadi pada kelompok siswa berkemampuan tinggi. Kondisi tersebut didukung tingkat kemampuan pemahaman yang dimiliki oleh siswa cenderung berbeda, kelompok siswa kategori tinggi memiliki kecendrungan kesadaran dan motivasi belajar yang baik. Sehingga hasil belajar yang diperoleh cenderung baik

Hasil perlakuan juga diperoleh beberapa nilai dalam proses pembelajaran, baik dari segi nilai LKS, afektif dan psikomotorik siswa. Hasil rata-rata tersebut dapat dilihat dari Tabel 3.

Tabel 3. Rekap rata-rata nilai LKS, afektif dan psikomotorik

\begin{tabular}{llccc}
\hline No & $\begin{array}{c}\text { Kelompok } \\
\text { Siswa }\end{array}$ & $\begin{array}{c}\text { Hasil } \\
\text { nilai } \\
\text { LKS }\end{array}$ & Afektif & Psikomotorik \\
\hline 1 & Tinggi & 81.25 & B & 84.70 \\
2 & Sedang & 76.24 & B & 83.62 \\
3 & Rendah & 74.78 & B & 80.33 \\
4 & Keseluruhan & 78.24 & B & 83.35 \\
\hline
\end{tabular}

Hasil nilai LKS, afektif dan psikomotorik menunjukkan nilai LKS siswa berkemampuan tinggi menghasilkan nilai yang paling baik yaitu rata-rata > 80, hasil nilai LKS terlihat perbedaan yag tidak terlalu tinggi pada siswa berkemampuan sedang dan rendah. Hasil afektif siswa rata-rata memiliki sikap yang baik yaitu rata-rata memperoleh nilai B. Hasil nilai psikomotorik mendapatkan nilai rata-rata $>80$ untuk tiap kelompok siswa. Hasil keseluruhan menunjukkan terjadinya peningkatan dari siswa berkemampuan rendah sampai tinggi.

\section{Hasil Metakognitif Siswa}

Hasil dari kemampuan metakognitif siswa diambil dari hasil rekapitulasi angket kemampuan metakognitif siswa sebelum dan sesudah perlakuan. Data pengaruh pembelajaran berbasis PBL terhadap kemampuan metakognitif siswa dapat dilihat dari hasil angket metakognitif. Hasil tersebut disajikan dari Tabel 4.

Tabel 4. Hasil angket metakognitif sebelum dan sesudah perlakuan

\begin{tabular}{ccccc}
\hline Proses & $\begin{array}{c}\text { Nilai } \\
\text { Rata- } \\
\text { Rata } \\
(\boldsymbol{\%})\end{array}$ & $\begin{array}{c}\text { Nilai } \\
\text { Maksimum } \\
(\boldsymbol{\%})\end{array}$ & $\begin{array}{c}\text { Nilai } \\
\text { Minimum } \\
(\mathbf{\%})\end{array}$ & $\begin{array}{c}\text { N- } \\
\text { gain }\end{array}$ \\
\hline $\begin{array}{c}\text { Sebelum } \\
\text { perlakuan }\end{array}$ & 63.89 & 75 & 53.3 & 0,36 \\
\hline
\end{tabular}

Hasil angket metakognitif sebelum dan sesudah perlakuan menunjukkan adanya peningkatan sebesar 0,36. Kondisi tersebut menunjukkan terdapat kecenderungan terjadi peningkatan pada kategori sedang. Hasil angket metakognitif juga dikategorikan sesuai level metakognitif yang disajikan pada Tabel 5 .

Tabel 5. Hasil level metakognitif siswa

\begin{tabular}{clcccc}
\hline $\begin{array}{c}\text { Rentang } \\
\text { sekor } \\
(\%)\end{array}$ & $\begin{array}{c}\text { Level } \\
\text { metakognitif }\end{array}$ & $\begin{array}{c}\text { Sebelum } \\
\text { perlakuan }\end{array}$ & $\begin{array}{c}\text { Rata- } \\
\text { rata }\end{array}$ & $\begin{array}{c}\text { Sesudah } \\
\text { perlakuan }\end{array}$ & $\begin{array}{c}\text { Rata- } \\
\text { rata }\end{array}$ \\
\hline $\begin{array}{c}80-100 \\
\%\end{array}$ & Sangat tinggi & - & & & \\
$70-79 \%$ & Tinggi & 3 & 72.22 & 22 & 75.30 \\
$60-69 \%$ & Sedang & 24 & 64.03 & 3 & 68.89 \\
$45-59 \%$ & Rendah & 6 & 57.22 & - & \\
$>44 \%$ & Sangat & - & & - & \\
& rendah & & & & \\
\hline
\end{tabular}

Hasil angket metakognitif secara umum menunjukkan adanya peningkatan kemampuan level metakognitif sebelum dan sesudah perlakuan. Sebelum perlakuan rata-rata siswa masuk pada kategori level metakognitif sedang dan masih terdapat siswa yang masuk dalam kategori level metakognitif rendah. Setelah perlakuan terjadi peningkatan yang ditunjukkan dari rata-rata siswa masuk pada level metakognitif tinggi dan sudah tidak terdapat lagi siswa yang masuk pada level kemampuan metakognitif rendah. Hasil angket juga menunjukkan terjadinya kecenderungan siswa yang memiliki level kemampuan metakognitif sedang mampu meningkat pada level kemampuan metakognitif sangat tinggi. Hasil data tersebut terjadi dikarenakan penerapan perangkat berbasis PBL yang telah dikembangkan berpengaruh terhadap kemampuan level metakognitif siswa. Kondis tersebut didukung hasil penelitian dari Tosun \& Erdal (2013) yang menyatakan bahwa PBL lebih 
efektif dalam meningkatkan level kemampuan metakognitif siswa yang memiliki pengetahuan sains yang lemah.

Angket metakognitif di analisis dari aspek kemampuan metakognitif yaitu: 1) perencanaan, 2) manajeman, 3) monitoring, 4) pelaksanaan, 5) evaluasi. Untuk hasilnya disajikan pada Tabel 6.

Tabel 6. Analisis aspek kemampuan metakognitif

Hasil penerapan perangkat pembelajaran berbasis PBL menujukkan terjadinya peningkatan kemampuan metakognitif, khsusnya aspek perencanaan mengalami peningkatan sebesar 0,42 dan masuk dalam kategori sedang. Aspek kemampuan metakognitif perencanaan menglami peningkatan paling tinggi dibanding aspek kemampuan yang lain, kondisi tersebut dikarenakan oleh adanya lembar refleksi pembelajaran yang mampu menunjang kemampuan metakognitif. Lembar refleksi pembelajaran mempunyai pengaruh besar dalam menstimulus siswa untuk meningkatkan kesadaran belajar yang dimiliki. Hasil refleksi pembelajaran akan menstimulus siswa untuk belajar mengevaluasi kekurangan apa saja yang dialami pada saat proses pembelajaran. Siswa akan sadar apa yang dibutuhkan selama proses pembelajaran dan bagaimana memperbaiki kekurangan saat pembelajaran berlangsung. Jurnal refleksi tersebut menunjukkan siswa memiliki kecenderungan berusaha lebih untuk merencanakan pembelajaran yang lebih baik. Oleh sebab itu, aspek kemampuan metakognitif dalam hal perencanaan cenderung mengalami peningkatan. Kondisi tersebut di perkuat hasil penelitian Byurkof (2004) menyatakan bahwa PBL membantu mengembangkan kemampuan metakognitif khususnya kemampuan metakognitif dalam hal perencanaan

Hasil yang berbeda di tunjukkan pada kemampuan metakognitif aspek pelaksanaan, pada aspek pelaksanaan menunjukkan peningkatan paling rendah dibanding aspek kemampuan metakognitif lainya. Kemampuan metakognitif aspek pelaksanaan mengalami peningkatan sebesar 0,29 dan masuk pada kategori rendah. Kondisi tersebut terjadi karena siswa belum terbiasa atas kesadaran belajar yang dimiliki sehingga pada waktu pelaksanaan pembelajaran siswa belum mampu mengontrol kemampuan kognisi secara baik. Kondisi tersebut juga disebabkan oleh menurunya motivasi siswa dalam hal pelaksanaan pembelajaran. Perangkat yang dikembangkan khsusunya untuk LKS memuat terlalu banyak pertanyaan untuk menghubungkan konsep PBL dan metakognitif, sehingga siswa cenderung enggan untuk melaksanakan sesuai yang diharapkan.

kemampuan metakognitif secara keseluruhan baik perencanaan, menejemen, monitoring, pelaksanaan, evaluasi mengalami peningkatan, jadi dapat dikatakan bahwa penerapan perangkat pembelajaran berbasis $\mathrm{PBL}$ dan berorientasi pada kemampuan metakognitif

\begin{tabular}{lccccc}
\hline \multirow{2}{*}{ Tahap } & \multicolumn{2}{c}{ Sebelum } & \multicolumn{2}{c}{ Sesudah } & N- \\
\cline { 2 - 5 } & $\begin{array}{c}\text { Rata- } \\
\text { Rata }\end{array}$ & Metakognitif & $\begin{array}{c}\text { Rata- } \\
\text { Rata }\end{array}$ & Metakognitif & Gain \\
\hline $\begin{array}{l}\text { 1.Perencanaan } \\
\text { 2.Manajemen }\end{array}$ & 63.74 & Sedang & 79.22 & Tinggi & 0.42 \\
Informasi & 63.72 & Sedang & 74.83 & Tinggi & 0.30 \\
3.Monitoring & 64.18 & Sedang & 76.62 & Tinggi & 0.34 \\
4.Pelaksanaan & 61.11 & Sedang & 72.47 & Tinggi & 0.29 \\
5.Evaluasi & 63.45 & Sedang & 77.65 & Tinggi & 0.38 \\
\hline \multicolumn{1}{c}{ Rata-Rata } & 63.24 & & 76.16 & & 0.35 \\
\hline
\end{tabular}

mampu meningkatkan kemampuan metakognisi siswa

\section{Simpulan dan Saran}

Berdasarkan hasil penelitian dan pembahasan dadapati hasil sebagai berikut. Satu perangkat yang telah dikembangkan sudah memiliki karakteristik berbasis PBL yang beroerientasi kemampuan metakongintif siswa dan masuk pada kategori sudah layak karena didsari analisis kebutuhan pengembangan perangkat pembelajaran berbasis $\mathrm{PBL}$ yang berorientasi kemampuan metakognitif. Dua penggunaan perangkat pembelajaran berbasis $\mathrm{PBL}$ yang beroerientasi kemampuan metakognitif berpengaruh terhadap hasil belajar dan kemampuan metakognitif siswa dibuktikan dengan peningkatan baik pada hasil belajar dan aspek kemampuan metakognitif masuk pada kategori sedang

\section{Daftar Pustaka}

Akcay, B. 2009. Problem-Based Learning in Science Education. Department of Science Education. Istanbul, Istanbul University

Barab, S.A., Sadler,T.D., Heisel,C., Hickey, D., and Zuiker, S. 2010. "Erratum to: Relating Narrative, Inquiry, and Inscriptions:Supporting Consequential Play". Journal of Science Eduction Technology. Volume 19. Hal 387-407

Biryukov , P. 2004. Metacognitive Aspects Of Solving Combinatorics Problems Beer- 
Sheva.Kaye College Of Education BeerSheva.

Downing, K. 2008. Problem-based learning and the development of metacognition. Springer. High Educ Vol: 57:609-621

Downing, K. 2010. Problem-based learning and the development of metacognition. As. J. Education \& Learning. Convenor, Institutional Analysis Group. Hong Kong Volume 1 No. 2. Hal 601-621

Dyahwati, P. Enni. S.\& Rahayu,. R. S. 2013. "Pengembangan Perangkat Pembelajaran Berbasis Masalah Pada Materi Sistem Pencernaan Makanan Bervisi Pendidikan Karakter". Prodi Pendidikan Ilmu Pengetahuan Alam, Program Pascasarjana, Universitas Negeri Semarang, Indonesia. JISE. Volume 2 No. 1. Hal 27-31

Livingston., \& Jennifer. A (1997). Metacognition: An Overview. Online

Tersedia: http://gse.buffalo.edu/fas/shuell/cep564/m etacog.html. Di akses (20 Mei 2014)

Lubana. L., Andreas P. B. P., \& Edy, C. 2013. "Pengembangan Perangkat Pembelajaran Biologi Berbasis Kasus Dan Berorientasi Pendidikan Karakter". Program Pasca Sarjana Pendidikan Ilmu Pengetahuan
Alam Universitas Negeri Semarang Indonesia. JISE. Volume 2 No. 1. Hal 2-7

Panggayuh, v. 20017. Pengaruh Kemampuan Metakognitif Terhadap Prestasi Akademik Mahasiswa Pada Mata Kuliah Pemrograman Dasar. JIPI (Jurnal Ilmiah Penelitian dan Pembelajaran Informatika) Volume 02, Nomor 01

Suherman., Erman., \& Turmudi. (2001). Strategi Pembelajaran Matematika Kontemporer. Jurusan Pendidikan Matematika UPI. Bandung

Toit, S. D.,\& Gary, K. 2003.Metacognitive Strategies in the Teaching and Learning of Mathematics.Faculty of Education, University of the Free State

Tosun, C \& Erdal, S. 2013. "The Effects Of Problem-Based Learning On Metacognitive Awareness And Attitudes Toward Chemistry Of Prospective Teachers With Different Academic Backgrounds. Bartin University Turkey". Australian Journal of Teacher Education. Volume 38 | Issue 3 Article 4. Hal 61-72

Wulandari, N., Sjarkawi., \& Damris , M. 2011. "Pengaruh Problem Based Learning Dan Kemampuan Berpikir Kritis Terhadap Hasil Belajar Mahasiswa". Unifersitas jambi. Jurnal Pedagogi. Volume 1 No. 1. Hal 14-24. 